\title{
THE PREVENTION OF SENSORY NEURON DEGENERATION IN THE PIG, WITH SPECIAL REFERENCE TO THE RÔLE OF VARIOUS LIVER FRACTIONS ${ }^{1}$
}

\author{
By MAXWELL M. WINTROBE, CECIL MUSHATT,2 JOSEPH L. MILLER, JR.,3 \\ LAWRENCE C. KOLB, HAROLD J. STEIN,4 AND HERMANN LISCO \\ (From the Department of Medicine, the Sub-Department of Neurology and the Department of \\ Pathology, the Johns Hopkins University, Baltimore)
}

(Received for publication August 29, 1941)

In previous reports $(1,2)$ a description was given of abnormal gait and degeneration in the nervous system which developed in pigs under certain experimental conditions. It was suggested that these effects were the result of a dietary deficiency and evidence was presented which indicated that the changes took place in spite of adequate amounts of vitamin A, thiamin, riboflavin, nicotinic acid or vitamin $\mathrm{E}$. Inanition or mineral deficiency did not seem to play any rôle. It was shown that a nerve-protecting factor was present in liver and, to a lesser extent, in yeast.

In an attempt to discover the nature of this protective factor or factors, further experiments have been carried out in which the basal deficient diet has been supplemented by various crude sources of accessory factors, chiefly various fractions of liver. More recently the newer vitamins, pyridoxine, pantothenic acid and choline have been used in conjunction with thiamin, riboflavin and nicotinic acid. It is the purpose of this report to give an account of the observations dealing with crude substances. Particular interest attaches to the nerve-protecting value of different fractions of liver, for degeneration similar to that observed in the pigs occurs in many cases of pernicious anemia in man. The fractions of liver used were those

1 Aided by grants from Parke, Davis and Company and the Rockefeller Foundation Fluid Research Fund of the Johns Hopkins Medical School, and carried out in cooperation with the Bureau of Animal Industry, United States Department of Agriculture.

Synthesized vitamins were furnished by Merck and Company, Incorporated, crude sources of vitamins by Mead Johnson and Company and Parke, Davis and Company. Liver fractions were prepared by Parke, Davis and Company.

${ }^{2}$ Adrian Stokes Memorial Fellow, Trinity College, Dublin, and recipient of a grant from the Medical Research Council of Ireland.

${ }^{3}$ Mead Johnson Fellow in Medicine.

4 Fleischmann Fellow in Medicine. produced during the manufacture of a liver extract which is effective in the treatment of pernicious anemia.

The literature dealing with "lameness," "stiffness" and "posterior paralysis" in swine and the available information regarding specific substances necessary for the preservation of the integrity of the nervous system, were reviewed completely in an earlier report (2). Full details were also given regarding the general plan of the experiment, the management of the animals, their housing and diet, and the methods of study. Only a brief account, therefore, need be given here.

\section{GENERAL PROCEDURE}

Pigs of approximately 3 weeks of age were shipped to Baltimore from the Beltsville Research Center of the United States Department of Agriculture. The animals were given a basic diet consisting of crude casein ("New Process," Sheffield By-Products Company) 9.5 grams, sucrose 21.0 grams, lard 4.0 grams and swine salt mixture Number 3 (2) 1.9 grams, per "unit." This amount ("one unit"), which furnishes 152 calories, or a fraction of a unit, was fed per kilogram body weight daily. The basic diet was supplemented with cod liver oil (Mead Johnson, 1800 units $A$ and 175 units D per gram) 0.5 gram per kilogram body weight per day and powdered brewers' yeast (Mead Johnson) 3 grams per kilogram per day.

This diet appears to be adequate for the normal growth and development of young pigs. Weaning is usually accomplished satisfactorily although poor growth at first and even episodes of diarrhea may complicate the transition period. After the animals became accustomed to the diet, and once growth and general nutrition were satisfactory, they were divided into groups, usually consisting of 3 pigs each, composed of representatives of different litters which were as similar as possible as regards weight.

In all our experiments the neurological changes have been the same and have been confined to the sensory neuron, so that for the purpose of comparison they can be graded, as was done in our previous report (2). Briefly restated, the degrees of degeneration are classified as follows: 
0

1 or +

2 or ++

3 or +++
No lesions.

Definite changes in the peripheral nerves only: these consist in myelin degeneration with free fat granules and swollen neurilemmal cells. (When there is less extensive change in the peripheral nerves with only Marchi degeneration demonstrable, the lesion is sometimes graded as $1 / 2$ or \pm .)

The above changes are accompanied by chromatolytic changes in the cells of the posterior root ganglia.

Degeneration of the posterior roots and the root entry zone of the spinal cord, in addition to the ganglion cell and peripheral nerve changes already noted.
4 or ++++ Conspicuous degenerative changes in the nerves, ganglia, roots and posterior funiculi of the spinal cord.

\section{PROTOCOLS : EXPERIMENT IV}

Objects. (1) To gain further evidence regarding the protective value of whole desiccated liver and of brewers' yeast; (2) to determine whether the protective substance is present in wheat germ and alfalfa; (3) to obtain preliminary information regarding the protective value of the antipernicious anemia fraction of liver.

Conditions of experiment (Figure 1). Fifteen pigs derived from two litters were fed brewers' yeast (Mead

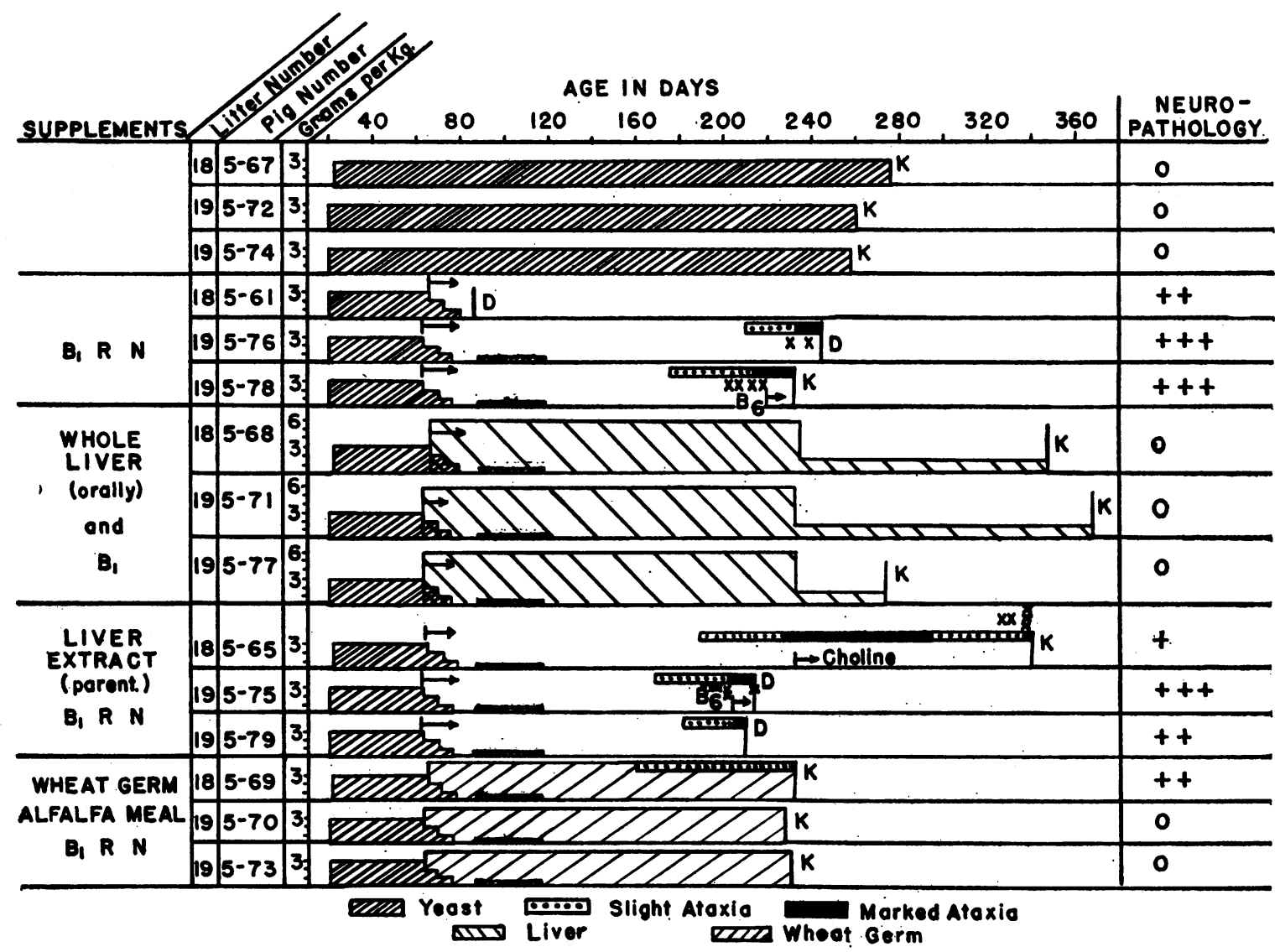

Fig. 1. Experiment IV. The Development of "Ataxia," Convulsions and Neuropathology in Pigs Given Only Thiamin, Riboflavin and Nicotinic Acid in the Place of Substances Contained in Yeast and in Whole Liver, Compared With the Complete Protection Afrorded by Yeast or Liver

Liver extract, injected intramuscularly, gave no protection in the doses used and wheat germ plus alfalfa meal was less effective than whole liver or yeast.

All the pigs received the same basal diet. The amount of yeast and the length of time it was fed are shown. Supplements were started when yeast reduction commenced, as indicated by the arrows. For amounts see text. $B_{1}$ refers to thiamin; $R$ to riboflavin; $N$ to nicotinic acid.

The time of onset and severity of ataxia are indicated. The crosses mark the occurrence of convulsions. D indicates that the animal was found dead, $\mathrm{K}$ that it was sacrificed.

Pig 5-65 was given choline from the age of 233 days. 
Johnson), 3 grams per kilogram body weight daily, until they were 63 to 67 days of age. In all but one group the amount of yeast fed was then gradually reduced so that after 13 days none was given. After a period of 15 days yeast was given again for 28 days in amounts of 0.5 gram per kilogram body weight daily. This was done in order to produce a less acute deficiency than would follow the sudden and complete withdrawal of yeast.
Supplements were added from the time the yeast was first reduced (63 to 67 days of age) (Table I and Figure 1). The quantities of thiamin, riboflavin and nicotinic acid given were the amounts estimated as present in the yeast which had been withdrawn; namely, thiamin 0.17 milligram, riboflavin 0.067 milligram, and nicotinic acid 0.4 milligram per gram of yeast.

Desiccated whole liver, which was fed as a supple-

TABLE I

\begin{tabular}{|c|c|c|c|c|c|c|c|c|c|c|c|c|}
\hline Nature of supplement* & $\underset{\text { num- }}{\text { Pig }}$ & $\begin{array}{c}\text { Litter } \\
\text { num- } \\
\text { ber }\end{array}$ & Sex & $\begin{array}{l}\text { Age yeast } \\
\text { reduction } \\
\text { began }\end{array}$ & $\begin{array}{c}\text { Time } \\
\text { ensuing } \\
\text { before } \\
\text { "ataxia" } \\
\text { began }\end{array}$ & $\begin{array}{c}\text { Dura- } \\
\text { tion } \\
\text { of } \\
\text { experi- } \\
\text { ment } \dagger\end{array}$ & $\begin{array}{l}\text { Age } \\
\text { at } \\
\text { death }\end{array}$ & $\begin{array}{c}\text { Aver- } \\
\text { age } \\
\text { daily } \\
\text { gain in } \\
\text { weight }\end{array}$ & \multicolumn{2}{|c|}{$\begin{array}{c}\text { Blood at } \\
\text { time of } \\
\text { death }\end{array}$} & Nature of death & $\begin{array}{l}\text { Neuro- } \\
\text { path- } \\
\text { ology }\end{array}$ \\
\hline & & & & days & days & days & days & grams & $\begin{array}{c}\text { red } \\
\text { blood } \\
\text { cells, } \\
\text { millions }\end{array}$ & 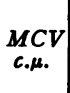 & & \\
\hline
\end{tabular}

EXPERIMENT IV

\begin{tabular}{|c|c|c|c|c|c|c|c|c|c|c|c|c|}
\hline $\begin{array}{l}\mathbf{B}_{1}, \mathbf{R}, \mathbf{N} \\
\mathrm{B}_{1}, \mathrm{R}, \mathrm{N}\end{array}$ & $\left|\begin{array}{r}5-76 \\
5-78\end{array}\right|$ & $\begin{array}{l}19 \\
19\end{array}$ & $\mathbf{F}$ & $\begin{array}{l}64 \\
64\end{array}$ & $\begin{array}{l}111 \\
112\end{array}$ & $\begin{array}{l}180 \\
169\end{array}$ & $\begin{array}{l}244 \\
232\end{array}$ & $\begin{array}{l}156 \\
178\end{array}$ & $\begin{array}{l}4.98 \\
4.65\end{array}$ & $\begin{array}{l}48 \\
56^{* *}\end{array}$ & $\begin{array}{l}\text { Died. Rectal ob- } \\
\text { struction and pro- } \\
\text { lapse of rectum. } \\
\text { Died (cause ?). } \\
\text { Killed. }\end{array}$ & $\begin{array}{l}+++ \\
++\end{array}$ \\
\hline $\begin{array}{l}\text { Des. liver, } B_{1} \\
\text { Des. liver, } B_{1} \\
\text { Des. liver, } B_{1}\end{array}$ & $\begin{array}{r}5-68 \\
5-71 \\
5-77\end{array} \mid$ & $\begin{array}{l}18 \\
19 \\
19\end{array}$ & $\begin{array}{l}\mathbf{F} \\
\mathbf{M} \\
\mathbf{F}\end{array}$ & $\begin{array}{l}66 \\
64 \\
64\end{array}$ & & $\begin{array}{l}281 \\
304 \\
209\end{array}$ & $\begin{array}{l}347 \\
368 \\
273\end{array}$ & $\begin{array}{l}346 \\
433 \\
567\end{array}$ & $\begin{array}{l}9.35 \\
7.40 \\
7.10\end{array}$ & $\begin{array}{l}55 \\
61 \\
64\end{array}$ & $\begin{array}{l}\text { Killed. } \\
\text { Killed. } \\
\text { Killed. }\end{array}$ & $\begin{array}{l}\mathbf{0} \\
\mathbf{0} \\
\mathbf{0}\end{array}$ \\
\hline $\begin{array}{l}\text { Parenteral liver ext., } \\
\text { i.m., } \mathbf{B}_{\mathbf{1}}, \mathbf{R}, \mathbf{N} \ddagger\end{array}$ & $5-65$ & 18 & $\mathbf{M}$ & 66 & 117 & 275 & 341 & 173 & 8.45 & 45 & Killed. & + \\
\hline $\begin{array}{l}\text { Parenteral liver ext., } \\
\text { i.m., } B_{\mathbf{1}}, \mathbf{R}, \mathbf{N}\end{array}$ & $5-75$ & 19 & $\mathbf{M}$ & 64 & 99 & 147 & 211 & 141 & 5.83 & $49^{* *}$ & Killed. & $+t+$ \\
\hline $\begin{array}{l}\text { Parenteral liver ext., } \\
\text { i.m., } B_{1}, R, N\end{array}$ & $|5-79|$ & 19 & & 64 & 120 & 147 & 211 & 143 & 5.35 & 43 & Killed. & ++ \\
\hline $\begin{array}{l}\text { Wheat germ, alf., } \\
B_{1}, R, N\end{array}$ & $5-69$ & 18 & $\mathbf{F}$ & 65 & 86 & 167 & 232 & 296 & 7.82 & 52 & Killed. Cirrhosis. & ++ \\
\hline $\begin{array}{l}\text { Wheat germ, alf., } \\
\mathbf{B}_{1}, \mathbf{N}\end{array}$ & $5-70$ & 19 & $\mathbf{M}$ & 64 & & 166 & 229 & 482 & 8.95 & 54 & Killed. Cirrhosis. & $\mathbf{0}$ \\
\hline $\begin{array}{l}\text { Wheat germ, alf., } \\
\mathbf{B}_{\mathbf{1}}, \mathrm{R}, \mathrm{N}\end{array}$ & $5-73$ & 19 & $\mathbf{M}$ & 64 & & 168 & 231 & 440 & 7.43 & 59 & Killed. Cirrhosis. & 0 \\
\hline Yeast continued & $5-67$ & 18 & F & reducer & & & 276 & $169 \dagger$ & 7.40 & 56 & Killed. & 0 \\
\hline Yeast continued & $5-72$ & 19 & $\mathbf{M}$ & Not & & & 259 & $297 \dagger$ & 6.90 & 61 & Killed. & 0 \\
\hline Yeast continued & 5-74 & 19 & $\mathbf{M}$ & $\begin{array}{l}\text { Nct } \\
\text { reduised }\end{array}$ & & & 258 & $406 t$ & 6.90 & 63 & Killed. & 0 \\
\hline
\end{tabular}

* $B_{1}$ refers to thiamin, $\mathrm{R}$ to riboflavir, $\mathrm{N}$ to nicotinic acid; "des. liver" is whole liver dried at a low temperature; parenteral liver extract is a crude anti-pernicious anemia liver extract $\left(1 \mathrm{cc} .=\frac{1}{\mathrm{t}}\right.$ unit); alf. is alfalfa meal. Details concerning the various fractions of liver are given in the protocols of the experiments. Unless otherwise stated supplements were given orally; i.m. = intramuscularly.

† By "duration of experiment" is meant the period of time from the day on which yeast was reduced and supplements were started to the day of death. The average daily weight gain is calculated for this period. In the case of the 3 pigs in which the quantity of yeast was not reduced at any time, the average daily weight gain is calculated from the ages of 63 to 65 days to the day of death.

I Pig 5-65 received choline during the course of the experiment. See text.

8 Pig 5-96 received choline and pyridoxine $\left(B_{6}\right)$ for a long period. See text.

1 Pig 6-00, at 246 days of age, received pyridoxine $50 \mathrm{mgm}$. intravenously, followed by the same dose the next, day, and riboflavin $30 \mathrm{mgm}$. intravenously on the following day.

I For explanation of grading see "General Procedure."

* The blood values recorded are those found after convulsions had occurred and before pyridoxine was given. Following the administration of vitamin $B_{6}$ the red cell count of pig 5-78 was 4.93 million and the M.C.V. 61 c. $\mu$; pig 5-75, R.B.C. 7.15, M.C.V. 51 c. $\mu$; pig 6-00, R.B.C. 6.75, M.C.V. 57; pig 6-08, R.B C. 6.68, M.C.V. 45.

M.C.V. is mean corpuscular volume. 
TABLE I-Continued

\begin{tabular}{|c|c|c|c|c|c|c|c|c|c|c|c|c|}
\hline \multirow[t]{2}{*}{ Nature of supplement* } & \multirow[t]{2}{*}{$\underset{\substack{\text { nig } \\
\text { ber }}}{\text { pig }}$} & \multirow{2}{*}{$\mid \begin{array}{c}\text { Litter } \\
\text { num- } \\
\text { ber }\end{array}$} & \multirow{2}{*}{\multicolumn{2}{|c|}{ Sex $\begin{array}{c}\text { Age yeast } \\
\text { reduction } \\
\text { began }\end{array}$}} & \multirow{2}{*}{$\begin{array}{c}\begin{array}{c}\text { Time } \\
\text { ensuing } \\
\text { beforee } \\
\text { "ataxia" } \\
\text { began }\end{array} \\
\text { days }\end{array}$} & \multirow{2}{*}{$\begin{array}{c}\begin{array}{c}\text { Dura- } \\
\text { tion } \\
\text { of } \\
\text { experi- } \\
\text { ment† }\end{array} \\
\text { days }\end{array}$} & \multirow{2}{*}{$\begin{array}{c}\begin{array}{c}\text { Age } \\
\text { at } \\
\text { death }\end{array} \\
\\
\text { days }\end{array}$} & \multirow{2}{*}{$\begin{array}{c}\begin{array}{c}\text { Aver- } \\
\text { age } \\
\text { daily } \\
\text { gain in } \\
\text { weight }\end{array} \\
\\
\text { grams }\end{array}$} & \multicolumn{2}{|c|}{$\begin{array}{l}\text { Blood at } \\
\text { time of } \\
\text { death }\end{array}$} & \multirow[t]{2}{*}{ Nature of death } & \multirow[t]{2}{*}{$\begin{array}{l}\text { Neuro- } \\
\text { path- } \\
\text { ology }\end{array}$} \\
\hline & & & & & & & & & $\begin{array}{c}\text { rea } \\
\text { cellls, } \\
\text { millions }\end{array}$ & $\underset{c, \mu .}{M C V}$ & & \\
\hline
\end{tabular}

EXPERIMENT V

\begin{tabular}{|c|c|c|c|c|c|c|c|c|c|c|c|c|}
\hline $\begin{array}{l}\text { Des. liver, } \mathbf{B}_{1}, \mathbf{R}, \mathbf{N} \\
\text { Des. liver, } \mathbf{B}_{1}, \mathbf{R}, \mathbf{N} \\
\text { Des. liver, } \mathbf{B}_{1}, \mathbf{R}, \mathbf{N}\end{array}$ & $\begin{array}{l}5-88 \\
6-04 \\
6-09\end{array}$ & $\begin{array}{l}20 \\
21 \\
22\end{array}$ & $\begin{array}{l}\mathbf{M} \\
\mathbf{F} \\
\mathbf{M}\end{array}$ & $\begin{array}{l}94 \\
80 \\
76\end{array}$ & & $\begin{array}{l}264 \\
231 \\
272\end{array}$ & $\begin{array}{l}358 \\
317 \\
348\end{array}$ & $\begin{array}{l}241 \\
225 \\
155\end{array}$ & $\begin{array}{l}6.90 \\
9.00 \\
8.60\end{array}$ & $\begin{array}{l}59 \\
56 \\
55\end{array}$ & $\begin{array}{l}\text { Killed. } \\
\text { Killed. } \\
\text { Killed. }\end{array}$ & $\begin{array}{l}\mathbf{0} \\
\mathbf{0} \\
\mathbf{0}\end{array}$ \\
\hline $\begin{array}{l}\text { Press cake fraction, } \\
\quad B_{1}, R, N\end{array}$ & $5-87$ & 20 & $\mathbf{M}$ & 94 & 184 & 191 & 285 & 301 & 7.90 & 49 & $\begin{array}{l}\text { Died. Subdural } \\
\text { hemorrhage and }\end{array}$ & + \\
\hline Press cake fraction, & $6-03$ & 21 & F & 80 & 193 & 196 & 276 & 186 & 5.48 & 45 & Died (cause? & + \\
\hline $\begin{array}{l}\text { Press cake fraction, } \\
\mathrm{B}_{1}, \mathrm{R}, \mathrm{N}\end{array}$ & $6-08$ & 22 & $\mathbf{M}$ & 80 & 177 & 216 & 292 & 207 & 4.31 & $48^{* *}$ & $\begin{array}{l}\text { Killed. Lobar } \\
\text { pneumonia. }\end{array}$ & ++ \\
\hline "Whipple" fraction, & $5-89$ & 20 & $\mathbf{M}$ & 94 & 72 & 93 & 187 & 151 & 4.55 & 55 & Killed. & ++ \\
\hline "Whipple" fraction, & $5-96$ & 20 & $\mathrm{~F}$ & 94 & 98 & 213 & 307 & 145 & 5.40 & 59 & Killed. & ++ \\
\hline $\begin{array}{l}\text { "Whipple" fraction, } \\
\mathrm{B}_{1}, \mathrm{R}, \mathrm{N}\end{array}$ & 6-05 & 22 & $\mathbf{M}$ & 76 & 72 & 93 & 169 & 250 & 5.00 & 50 & Killed. & ++ \\
\hline $\begin{array}{l}\text { "Cohn" fraction, } \\
\mathrm{B}_{1}, \mathrm{R}, \mathrm{N} \|\end{array}$ & $6-00$ & 21 & $\mathbf{M}$ & 80 & 198 & 267 & 347 & 232 & 5.33 & $47^{* *}$ & $\begin{array}{l}\text { Died. Pulmonary } \\
\text { congestion. }\end{array}$ & + \\
\hline $\begin{array}{l}\text { Parenteral liver ext., } \\
\mathbf{B}_{1}, \mathrm{R}, \mathrm{N}\end{array}$ & $5-95$ & 20 & F & 94 & & 225 & 319 & 208 & 3.44 & 47 & $\begin{array}{l}\text { Died. Gastric } \\
\text { hemorrhage. }\end{array}$ & 0 \\
\hline $\begin{array}{l}\text { Parenteral liver ext., } \\
\mathbf{B}_{1}, R_{\text {N }}\end{array}$ & 5-99| & 21 & $\mathbf{M}$ & 80 & & 181 & 261 & 243 & 6.40 & 47 & $\begin{array}{l}\text { Killed. Broncho- } \\
\text { pneumonia. }\end{array}$ & + \\
\hline $\begin{array}{l}\text { Parenteral liver ext., } \\
\mathbf{B}_{\mathbf{1}}, \mathrm{R}, \mathbf{N}\end{array}$ & $6-14$ & 22 & F & 76 & & 272 & 348 & 240 & 7.13 & 59 & Killed. & \pm \\
\hline $\begin{array}{l}\text { Permutit fraction, } \\
B_{1}, R, N\end{array}$ & $5-90$ & 20 & $\mathbf{M}$ & 94 & 83 & 96 & 190 & 137 & 5.20 & 38 & $\begin{array}{l}\text { Killed. Chronic } \\
\text { arthritis. }\end{array}$ & ++ \\
\hline Permutit fraction, & 6-02 & 21 & $\mathbf{M}$ & 80 & 58 & 59 & 139 & 241 & 7.75 & 50 & Died (cause?). & ++ \\
\hline $\begin{array}{l}\text { Permutit fraction, } \\
\mathrm{B}_{1}, \mathrm{R}, \mathrm{N}\end{array}$ & $5-11$ & 22 & $\mathrm{~F}$ & 76 & 92 & 119 & 195 & 143 & 7.62 & 55 & Killed. & +++ \\
\hline $\begin{array}{l}\text { Mixture of fractions, } \\
B_{1}, R, N\end{array}$ & $5-92$ & 20 & $\mathbf{M}$ & 94 & & 138 & 222 & 258 & 7.18 & 50 & $\begin{array}{l}\text { Died. Rectal ob- } \\
\text { struction. }\end{array}$ & 0 \\
\hline $\begin{array}{l}\text { Mixture of fractions, } \\
\mathbf{B}_{\mathbf{1}}, \mathbf{R}, \mathbf{N}\end{array}$ & $\mid 5-98$ & 21 & $\mathbf{M}$ & 80 & & 257 & 337 & 391 & 7.25 & 66 & Killed. & 0 \\
\hline $\begin{array}{l}\text { Mixture of fractions, } \\
B_{1}, R, N\end{array}$ & $6-12$ & 22 & $\mathbf{M}$ & 76 & & 260 & 336 & 246 & 7.40 & 59 & Killed. & 0 \\
\hline
\end{tabular}

ADDITIONAL ANIMALS

\begin{tabular}{c|c|c|c|c|c|c|c|c|c|c|l|c}
\hline $\begin{array}{c}\text { Parenteral liver ext., } \\
\text { i.m., B B , R, N } \\
\begin{array}{c}\text { Parenteral liver ext. } \\
\text { (oral), B } \mathrm{B}_{1}, \mathrm{R}, \mathrm{N}\end{array}\end{array}$ & $6-50$ & 24 & $\mathrm{~F}$ & 94 & 131 & 195 & 289 & 164 & 7.48 & 50 & Killed. & ++ \\
\hline
\end{tabular}

ment to 3 pigs, was given in amounts of 6 grams per kilogram body weight per day for 169 days, after which time only 1.5 grams per kilogram were fed. The preparation used was hog liver, dried in vacuo at a low temperature (below $40^{\circ} \mathrm{C}$.). One and one-half grams were derived from 5 grams of fresh wet liver. Since the thiamin content of liver is lower than that of yeast, this vitamin was given, in the doses already mentioned, to those pigs receiving desiccated whole liver.

The anti-pernicious anemia liver extract used was a 
crude extract (Parke, Davis) assayed at $1 / 2$ unit (U.S.P.) anti-anemic value per cc. It was given subcutaneously, $0.66 \mathrm{cc}$. per kilogram once a week for 15 weeks and then twice a week for the next 6 weeks. The one animal surviving beyond this time was given a total dose of 20 cc. twice weekly until it was killed. This represented an average amount of $1.0 \mathrm{cc}$. per kilogram per week.

Wheat germ (Sealtest Laboratories) was fed in amounts of 6 grams per kilogram per day and alfalfa meal 5 grams per kilogram per day.

Ascorbic acid, 16 milligrams per kilogram, was given orally three times a week throughout their lifetime to all the pigs in this experiment except pigs $5-67,5-72$ and 5-74.

Results (Figure 1, Table I). Confirming our previous observations, abnormal gait and extensive degeneration in the nervous system developed in the pigs which were given only thiamin, riboflavin and nicotinic acid in addition to the basal diet, cod liver oil and ascorbic acid. On the other hand, desiccated whole liver plus thiamin afforded protection even in animals observed for a very long time. The period of observation in the animals which were given yeast as the only supplement was not as long as in the case of those given liver but it was equal to that of the animals given only thiamin, riboflavin and nicotinic acid. The gait of the animals fed only yeast supplement was normal in all instances in Experiment IV and no histologic changes could be found at autopsy.

It will be noted that the record of wheat germ plus alfalfa meal, given in addition to thiamin, riboflavin and nicotinic acid, is not as good as that of desiccated whole liver or yeast, for one animal developed incoordination in gait and degenerative changes were found in the nervous system. It is of interest to note that cirrhosis of the liver was found in all 3 of these animals but was absent in the rest of our pigs. Cirrhosis of the liver has been described as a manifestation of nutritional deficiency in rabbits (3).

The anti-pernicious anemia fraction of liver, given parenterally in addition to thiamin, riboflavin and nicotinic acid, which were administered orally, failed, in the doses used, to produce a result significantly better than that in animals given these vitamins alone.

Choline chloride, $10 \mathrm{mgm}$. per $\mathrm{kgm}$. per day, was given orally to pig 5-65 167 days after yeast had been replaced by thiamin, riboflavin and nicotinic acid, given orally, and parenteral liver ex- tract, given intramuscularly. A well pronounced slapping gait had been present for two months and this animal's experimental mates had already died following the development of ataxia and other signs of deficiency, including convulsions in one of them (Figure 1). The ataxia did not progress once the administration of choline was started. Weight gain occurred and, after 2 months, definite improvement in gait was noted. Some improvement in the general appearance of the animal also took place and after almost 3 months of choline administration no abnormality in gait could be noted. This improvement did not persist, however. For a period of 3 weeks a slight abnormality in gait was perceptible, then definite ataxia appeared and in another week an epileptiform convulsion occurred. Following this the gait deteriorated considerably and repeated convulsions took place. The animal was finally sacrificed.

The growth and general development of the animals fed liver, wheat germ and alfalfa meal, or yeast, were good, while in the remainder they were less satisfactory (Table I). In the pigs given only thiamin, riboflavin and nicotinic acid, and in those given the anti-pernicious anemia fraction of liver in addition to these vitamins, a generally untidy appearance, diarrhea and loss of appetite occurred; in several even vomiting accompanied the onset of abnormal gait. The vomiting and diarrhea ceased after several days, possibly as the result of the administration of 11 grams of yeast daily for several days, but the untidy appearance persisted. Later diarrhea recurred in several animals in episodes of 3 or 4 days' duration and disappeared spontaneously.

Epileptiform convulsions were observed in 2 of the 3 pigs receiving thiamin, riboflavin and nicotinic acid as the only supplements and in 2 of the 3 animals receiving injections of liver extract in addition to thiamin, riboflavin and nicotinic acid by mouth. The single member of the first group in which convulsions were not observed (5-61) died at a very early age. The convulsions first appeared when the pigs were 197 to 329 days of age, and after the experiment had been in progress 137 to 263 days.

Preceding the convulsion it was usually noted that the pig was excited and "nervous." Further excitement such as the rattle of the food pans or that produced by allowing the pig into a runway 
in order to observe its gait would sometimes precipitate an attack. Frequently the pig would run at great speed up and down the runway and then would collapse. The convulsions varied in intensity but in general the pattern was as follows: the pig lay on its side, all four limbs and the muscles of the body jerked rapidly, the head was held in extension, the eyes were shut or turned upwards and saliva drooled from the mouth. After several minutes, the spasmodic muscular contractions ceased and a stage of stupor followed which also lasted several minutes. Occasionally a gurgling sound could be heard. When the stupor was over the pig would try to get up and, when it finally succeeded, it would proceed in a staggering, dazed fashion. An animal previously able to run at a furious pace would stumble and fall repeatedly. In several animals ataxia appeared for the first time following a convulsion and progressed rapidly from then on.

Once convulsions set in they were often repeated at intervals of several days, sometimes more often (Figure 1). Pig 5-78, following the fifth convulsion, was given pyridoxine hydrochloride, 100 mgm. intravenously, followed the next day by the same dose together with $30 \mathrm{mgm}$. thiamin chloride. During the following 11 days the same dose of thiamin, together with $10 \mathrm{mgm}$. pyridoxine, was given daily intravenously. No further convulsions were observed but the animal remained very clumsy and ataxic. Pig 5-75, following six convulsions in the same number of days, was helpless and unable to stand. Pyridoxine, $100 \mathrm{mgm}$., was given daily intravenously for the remaining 8 days before the pig died. The state of helplessness was unchanged, but no further convulsions were observed until the day of death when one more was noted.

In pig 5-65 convulsions appeared at a much later date than in the other pigs. This animal differed from the others in that it was given choline for a long time, as already described. Five convulsions were observed occurring in rapid succession in the 13 days preceding death.

Severe anemia (Figure 2) was observed in 2 of the pigs given only thiamin, riboflavin and nicotinic acid (5-76, 5-78) and in 2 given parenteral liver extract in addition (5-75, 5-79). The first 2 animals developed anemia at the same time that other signs of deficiency appeared (untidy appearance, loss of appetite, diarrhea, vomiting). Following the administration of a very small amount of yeast ( 0.5 gram per $\mathrm{kgm}$. daily for 11 days) the anemia was promptly relieved (Figure 2). After 3 weeks anemia recurred and gradually became more severe than it was originally. Following the administration of pyridoxine and thiamin to pig 5-78, a slight decrease of anemia of questionable significance occurred.

The anemia in the 2 pigs given parenteral liver extract was steadily progressive and terminally it developed very rapidly. One of these animals, 5-75, was given pyridoxine. The doses were larger than those given 5-78, and a prompt and substantial rise in the blood count followed (Figure 2).

As the anemia developed, increasing anisocytosis but practically no poikilocytosis or hypochromia appeared. A few polychromatophilic macrocytes were noted, but the most striking change was the appearance of microcytes, some extremely small. When the anemia became quite severe, a well marked decrease in the mean corpuscular volume was found.

\section{EXPERIMENT V}

Object. To obtain further information regarding the nature of the factor or factors in whole liver which protect the nervous system of the pig.

Conditions of experiment. In the process of manufacture of liver extract for the treatment of pernicious anemia, hog liver is digested at $\mathrm{pH} 5$, then heated at $85^{\circ}$ C. and filtered. The residue is known as the filter press cake and ordinarily is discarded. The filtrate, after reduction to small volume at a low temperature in vacuo, is treated with alcohol added in amounts to make a 70 per cent concentration. A precipitate forms which is sometimes known as the Whipple "secondary anemia" fraction. The clear fluid obtained after removal of the 70 per cent alcohol precipitate by filtration is known as the Cohn anti-pernicious anemia fraction. This can be desiccated as is done to obtain a dry preparation for oral administration in the treatment of pernicious anemia or it may be passed through permutit in order to prepare a fraction which can be given parenterally. The process can be outlined schematically as follows: 


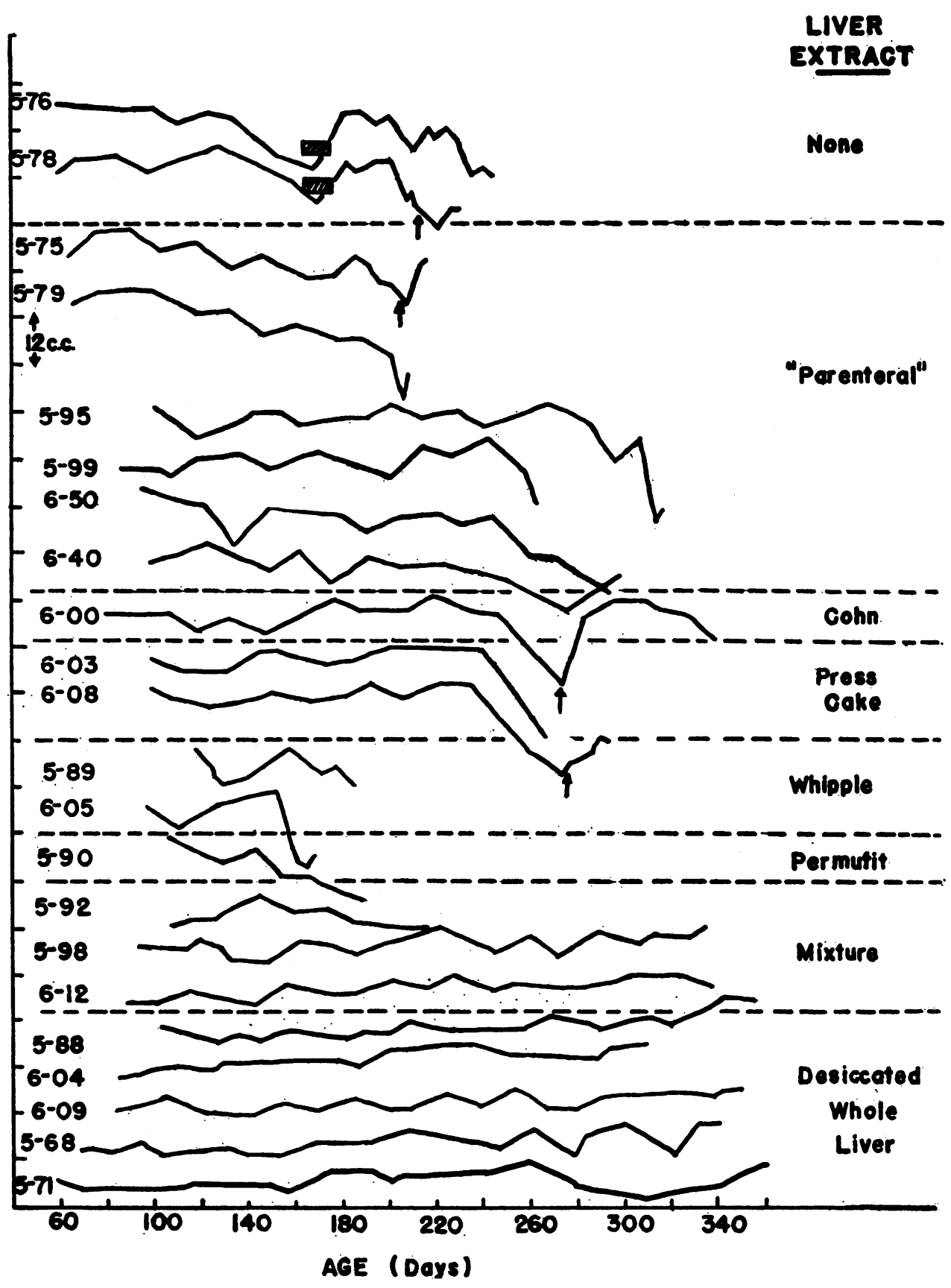

Fig. 2. The Development of Anemia in Pigs Fed an Artificial Diet Supplemented with Thiamin, Riboflavin and Nicotinic Acid and Various Liver Extracts

The continuous lines represent volume of packed red cells in cubic centimeters per 100 cubic centimeters of blood. The interrupted lines divide the various groups. The arrows represent the time of administration of pyridoxine in pigs 5-75 and 6-08 and of pyridoxine together with thiamin in 5-78 and with riboflavin in 6-00. The hatched areas represent the temporary administration of yeast to pigs 5-76 and 5-78.

Note the absence of anemia, as indicated by the essentially horizontal lines, in pigs fed the mixture of liver extracts or desiccated whole liver.

(For brevity, curves for the following pigs, none of which showed a significant degree of anemia, have been omitted: 5-77, desiccated whole liver; 5-65 and 6-14, parenteral liver extract; 5-87, press cake; 5-96, Whipple fraction; 6-02 and 6-11, permutit fraction; 5-67, 5-72 and 5-74, brewers' yeast; and 5-69, 5-70 and 5-73, wheat germ and alfalfa meal.)

Each division on the ordinate represents $12 \mathrm{cc}$. of packed red cells per $100 \mathrm{cc}$. blood. 


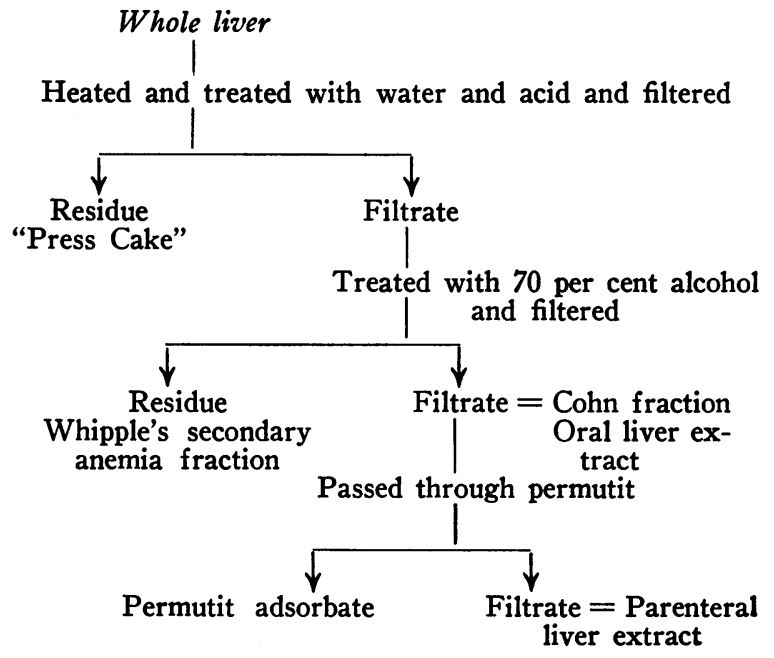

In order to assay these fractions, 21 pigs, weaned as already described, were divided at ages of 69 to 87 days into 7 comparable groups of 3 each. Yeast was withdrawn completely over a period of 2 weeks. From the time of the first reduction of yeast, the administration of thiamin, riboflavin and nicotinic acid, in the doses indicated in Experiment IV, and of whole liver or liver fractions, was commenced. The latter were given in the form of a dry powder mixed with the basal diet each day. All supplements were given orally.

For the purpose of this experiment a large amount of liver was processed in the plant of Parke, Davis and Company and all fractions were saved. The following are the amounts of the various fractions obtained per 5 grams fresh whole liver:

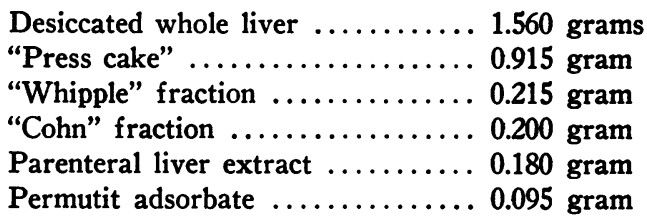

The amount of any fraction derived from 5 grams of fresh whole liver will be referred to here as one "equivalent." This amount of whole liver, per kilogram body weight, corresponds to the quantities of whole liver used at one time in the treatment of pernicious anemia ( 300 to $\mathbf{3 5 0}$ grams per patient per day).

One of the above six products was fed to each of a group of 3 pigs. At the start of the experiment the daily dose per kilogram was one equivalent in the case of the desiccated whole liver and two equivalents in the case of the various fractions. The double dose of the fractions was used because of the possibility that protective factors might have been lost in the process of manufacture. A seventh group of pigs was given the press cake, Whipple, parenteral liver extract and permutit fractions mixed in the proportions derived from 5 grams of fresh liver. These animals received 1.41 grams of the mixture per kilogram, or one equivalent.
As shown in Figure 3, the quantities of the liver fractions used were altered in the course of the experiment. Modifications were made in terms of "equivalents" of fresh liver and parallel changes were made in all groups.

Two of the 3 pigs fed the Cohn fraction died suddenly following a bout of diarrhea shortly after the experiment was commenced and have therefore been excluded from this report.

Results (Figure 3 and Table I). It was evident very early that the permutit fraction was lacking in essential growth factors and in factors needed for the protection of the nervous system. The same was true of the Whipple fraction. In the other groups of animals, on the other hand, no evidence of deficiency appeared at this period. The amounts of the press cake, Cohn, and parenteral liver extract fractions were therefore reduced from two to one "equivalent." This change was maintained for 56 days when a further reduction to one-half equivalent was made. Shortly after this reduction, evidence of abnormal gait appeared in the animals receiving press cake and in the pig fed the Cohn fraction. Since it was feared that the amounts of the extracts had been reduced to so low a level that abnormal gait might develop in all groups and that differences between them might thereby be obscured, 4 weeks after this last change the amount of supplement was increased to.one equivalent. No additional animals developed abnormalities in gait, but 2 of those receiving the parenteral liver extract were found on histologic examination to have demonstrable changes of mild degree in the nervous system. None of the pigs receiving the mixture of fractions or desiccated whole liver showed signs of incoordination or evidence of nerve lesions histologically.

The pigs fed desiccated whole liver and the mixture of liver extracts, respectively, grew rapidly (Figure 4). Those in the latter group looked particularly well developed and well nourished. The Cohn, parenteral liver extract and press cake fractions in the order named, were less satisfactory in promoting growth. A pronounced deficiency of growth factors was observed in the pigs fed the Whipple and the permutit fractions.

One of the pigs (5-96) fed the Whipple fraction was given choline chloride in the same doses as those used for pig 5-65 (Experiment IV). After 3 weeks pyridoxine, $0.3 \mathrm{mgm}$. per $\mathrm{kgm}$. daily, was also given. This animal lived consider- 


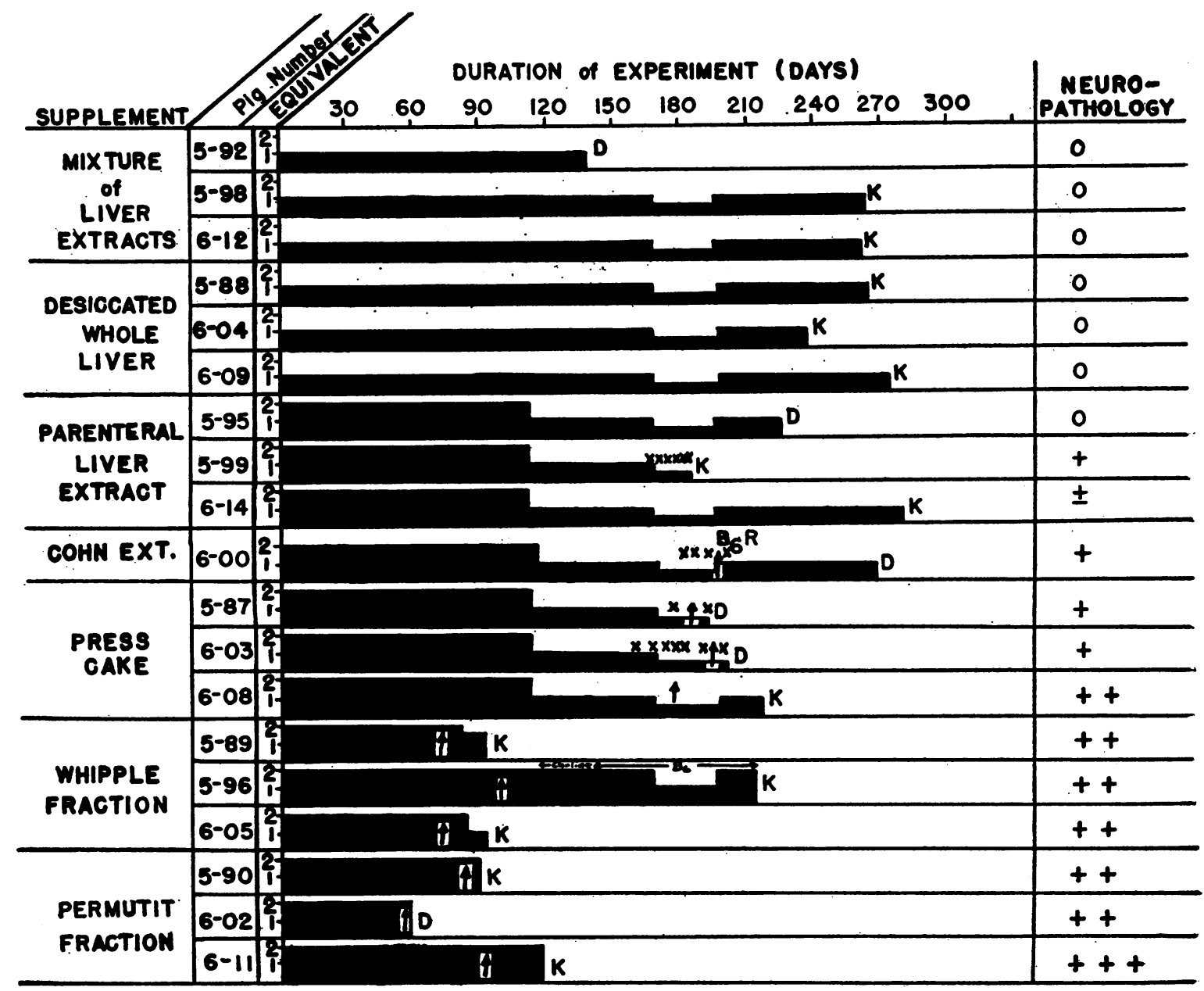

Fig. 3. Experiment V. The Relation of "Ataxia," Convulsions and Neuropathology to the Amount ANd Type of Liver Extract Fed

Each "equivalent" of a liver extract is the amount derived from 5 grams of fresh, whole liver. For further details see Table I and protocol. All pigs received thiamin, riboflavin and nicotinic acid.

The vertical arrows indicate the approximate date of onset of ataxia. The crosses represent convulsions. D indicates that the animal was found dead; $\mathrm{K}$ that it was sacrificed.

Pig 5-96 was given choline and pyridoxine during the period indicated.

ably longer than its mates, but no consistent improvement in gait occurred. There was no further weight gain and finally the animal deteriorated and became helpless. It was sacrificed 94 days after choline was first given.

Epileptiform convulsions, like those already described, were observed in 2 of the 3 pigs fed press cake, in one of those fed the parenteral liver extract and in the animal receiving the Cohn fraction (Figure 3). The last was the only pig treated with vitamins. This animal had had four observed convulsions and had reached a state of complete helplessness. Pyridoxine was given, 50 mgm. intravenously on 2 successive days. No additional convulsions were seen. However, there was only slight improvement in the degree of prostration and therefore on the third day $30 \mathrm{mgm}$. riboflavin were given intravenously. Three days later the animal was able to move about actively, the only abnormality present being the stamping gait characteristic of our "ataxic" animals.

Severe anemia was observed in 2 out of 3 pigs receiving the press cake fraction (Figure 2 and Table I). The third (5-87) developed microcy- 


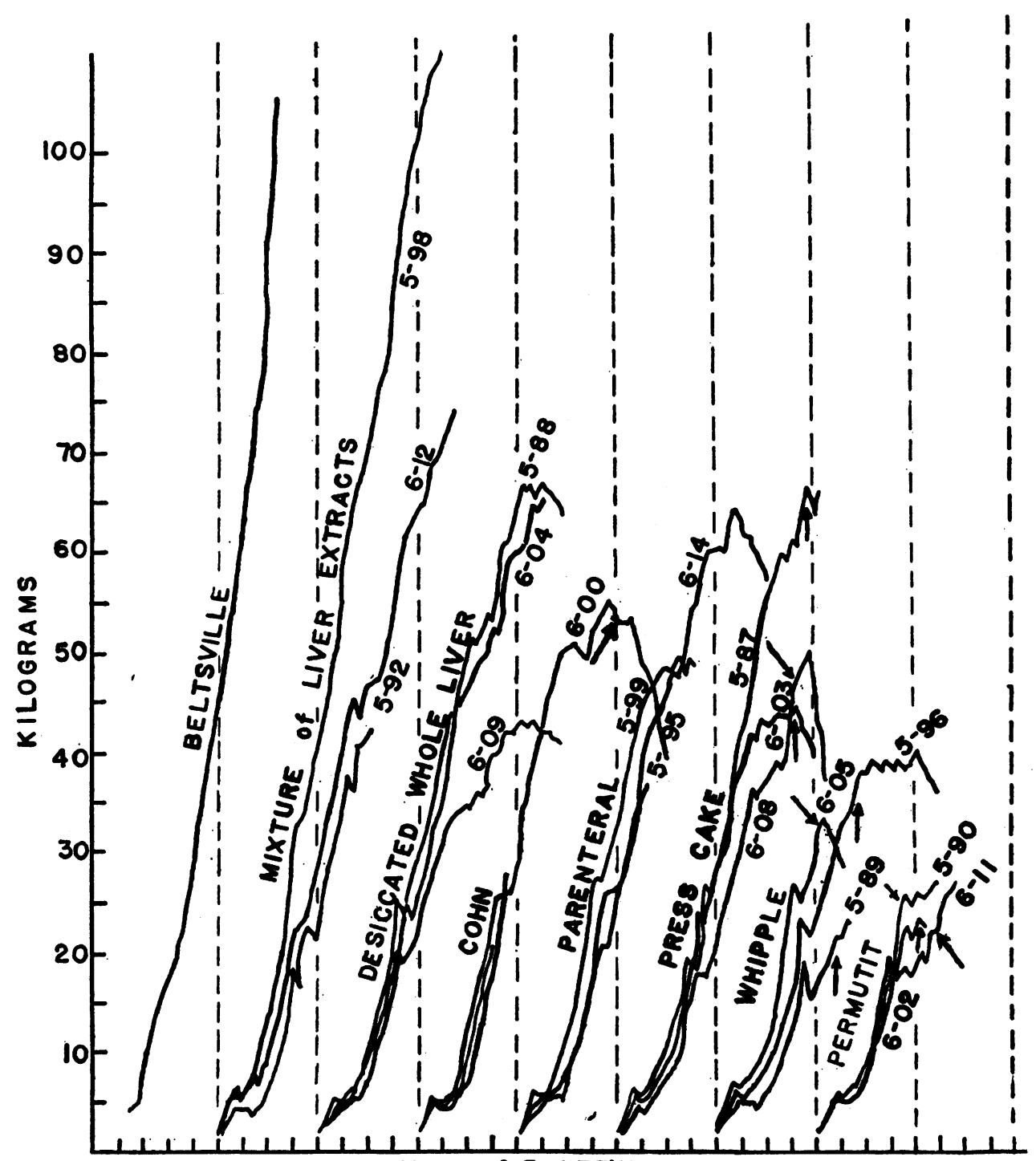

INTERVALS Of 5 WEEKS

Fig. 4. Growth of Pigs Receiving Desiccated Whole Liver, Various Liver Extracts and a Mixture of These Extracts, Compared with That of Pigs Raised at the Experimental Farm of the U. S. Department of Agriculture, Beltsville, Maryland.

Arrows indicate the onset of ataxia.

All pigs received one unit of diet (152 calories) per $\mathrm{kgm}$. until they were $4 \frac{1}{2}$ to 5 months of age, half a unit for the next 6 to 8 weeks, a third unit for the following 6 to 8 weeks, a half unit again for 4 weeks and a third of a unit thereafter.

tosis without severe anemia. One of these pigs (6-08) was treated with pyridoxine $(50 \mathrm{mgm}$. daily for 16 days) and a rise in red cell count without increase in the size of the cells followed. This pig's feet were ulcerated and bleeding, making interpretation of the results difficult. Anemia was present also in 2 pigs receiving the Whipple fraction. The third member of this group (5-96) developed no anemia. This pig differed from its mates in that it was given choline and pyridoxine in addition to the liver fraction. In the single pig fed the Cohn fraction (6-00) severe anemia and microcytosis developed. Following two injections of pyridoxine ( $50 \mathrm{mgm}$. each), together with one 

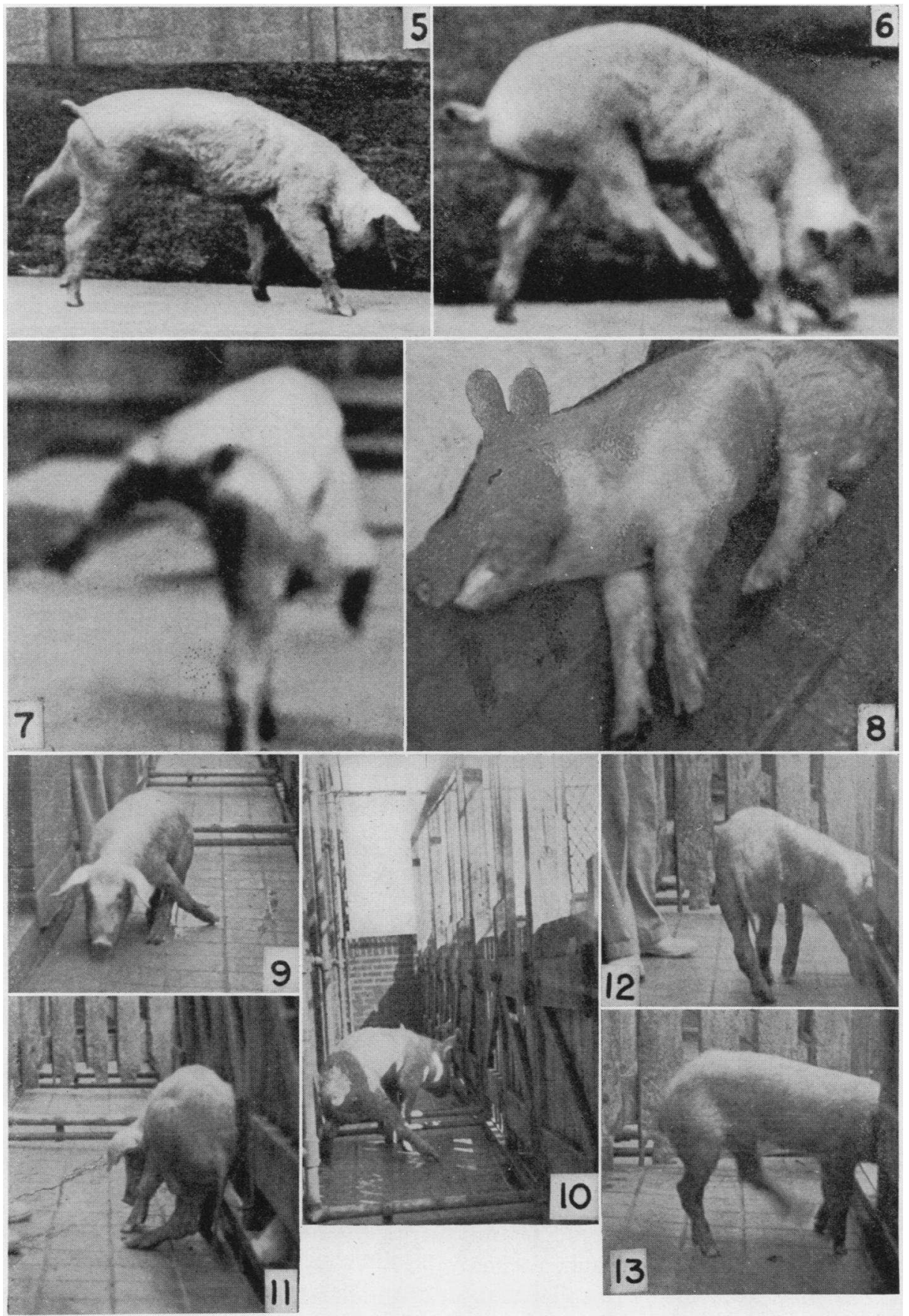

Figs. 5-13. Abnormal Gait in Various Pigs and Coma Following Convulsion in Pig 5-65

Figures 5, 6 and 7. Pig 5-96 ("Whipple" fraction of liver). In Figure 6, note the "goose-step," in Figure 7 the attempt to balance on two legs. Also note the malnutrition and the untidy appearance of the hair (Figure 5) so characteristic of pigs suffering from nutritional deficiency. These are enlargements from a motion picture film.

Figure 8. Pig 5-65 (parenteral liver extract) in a comatose state following a convulsion.

Figures 9 and 10. Pig 5-65, 2 weeks previously, showing the difficulty in controlling the fore and hind legs.

Figures 11, 12 and 13. Pig 6-05 ("Whipple" fraction of liver), showing the attempt to gain support by leaning against a pen (Figure 11), the swaying of the body on turning into the pen (Figure 12) and the groping motion of the left hind leg before it was set down on the ground (Figure 13). 
injection of riboflavin ( $30 \mathrm{mgm}$.), the reticulocytes increased from 4.2 per cent to 11.4 per cent on the fourth day following the first injection and the anemia was relieved in 6 days. Of the group receiving "parenteral" liver extract, anemia was observed in 2 out of 3 pigs. In one of these gastric hemorrhage occurred and accounted at least in part for the anemia. Severe anemia was found in only one of the pigs fed the permutit fraction of liver.

\section{DISCUSSION}

Protection of the nervous system. For the period of the experiments, the development of degenerative changes in the nervous system was prevented by feeding desiccated whole liver or brewers' yeast. Wheat germ together with alfalfa meal was more variable in effect. Desiccated whole liver gave protection in amounts derived from 5 grams fresh liver per kilogram body weight daily. The combination of fractions obtained from this quantity of liver was equally effective but none of the individual fractions, fed singly, gave complete protection. It should be pointed out that all the animals described here except those given yeast throughout the experiment received supplements of thiamin alone or thiamin, riboflavin and nicotinic acid in amounts adequate to prevent deficiencies of these substances.

The extract of liver which is used in the treatment of pernicious anemia was clearly the best of the extracts assayed. None of the 3 pigs receiving the parenteral fraction in Experiment $\mathrm{V}$ developed an abnormal gait. One was found free of histologic nerve changes and one showed peripheral nerve lesions detectable only by Marchi staining. Only one animal was found to have changes demonstrable by the Pal-Weigert or the Mahon stains for myelin.

Thus the pigs developed relatively mild neuropathological changes and no observed ataxia when fed one-half to one equivalent of the antipernicious anemia fraction per kilogram daily. This is in contrast to the more extensive neurological lesions, as well as definite ataxia, which occurred in animals given less (approximately onetenth equivalent) of a similar fraction parenterally (Experiment IV). Even the latter dose, however, is large when compared with the amounts effective on parenteral administration in relieving anemia in man. On the basis of this evidence, it appears that large amounts of the anti-pernicious anemia fraction are required by the pig.

The antianemic effect of liver extract in pernicious anemia is greatly enhanced by parenteral administration of the extract. In order to compare the value of "parenteral" liver extract when given orally and parenterally, respectively, 2 additional pigs (6-40 and 6-50, Table I) were given per kilogram body weight per day that amount of extract derived from 2 grams fresh liver. The experimental conditions were the same as those already described and thiamin, riboflavin and nicotinic acid were fed as in the animals already discussed. The liver extract was injected intramuscularly twice a week in one pig while the other pig received the same amount orally with its food twice a week. After 3 weeks the dose of extract was increased 50 per cent in both animals. Pig 6-40 finally received as much as 70 and even 80 cc. liver extract intramuscularly twice a week.

These quantities of liver extract, which were less than those fed the pigs in Experiment $V$, failed to protect the nervous system of pigs $6-40$ and $6-50$. The animal receiving injections grew more rapidly than its mate. The latter was thin and untidy in appearance, while the former looked wellnourished. However, an abnormal gait developed in pig 6-40 in spite of the appearance of good health. Ataxia was not observed in the pig fed liver extract. Histologically the latter animal showed a less severe degree of degeneration in the nervous system than pig 6-40.

It thus appears that there is no increase in the efficacy of liver extract in protecting the nervous system of young pigs when it is given parenterally.

Convulsions. Convulsions were observed in our animals after 5 or 6 months on a deficient diet. They occurred when only thiamin, riboflavin and nicotinic acid represented the " $B$ " vitamins or when "parenteral" liver extract, the Cohn fraction or the press cake fraction was furnished in addition to these vitamins. The cause of the convulsions is not altogether clear. One pig which died after a convulsion (5-87) was found to have a subdural hemorrhage, but in the other animals no anatomical lesions in the brain have been discovered in the sections studied so far.

That the convulsions were a manifestation of 
nutritional deficiency seems apparent for they have never been observed in animals receiving whole desiccated liver, a mixture of liver extracts which probably is equivalent to whole liver, brewers' yeast or wheat germ and alfalfa meal in addition to thiamin, riboflavin and nicotinic acid. Epileptiform convulsions have been observed in pigs (4), dogs $(5,6)$ and rats $(7)$ and have been attributed to pyridoxine deficiency.

Anemia. The anemia observed in our animals was no doubt due to nutritional deficiency for in those fed whole liver, yeast, wheat germ and alfalfa or the mixture of liver fractions, the blood was maintained at an essentially constant level. Why anemia was more pronounced in one pig fed a deficient diet than in another, or why a few on deficient diets failed to develop any anemia, is not evident. The anemia observed was similar to that described by others in dogs (8) and pigs (4) and has been attributed to pyridoxine deficiency.

Gastric analyses were performed in most of our pigs from time to time. No significant and consistent abnormalities were found.

Relation to pernicious anemia. Little can be added to what was stated in a previous publication (1) regarding the possible relationship of the degenerative changes in the nervous system of these pigs and those observed in some cases of pernicious anemia. The fact that the fraction of liver which is effective in relieving the anemia in the latter disease was more valuable in protecting the nervous system of pigs than the other liver fractions, is of interest. That large amounts of liver extract were necessary for this purpose is another point of similarity with pernicious anemia, for it is a generally held clinical impression that large quantities of liver or of crude liver extracts are required to effect any improvement or to prevent the advance of lesions in the nervous system of patients. Unlike the blood picture in pernicious anemia, macrocytic anemia was not observed in our animals.

It remains to be proved that the changes in the nervous system observed in the pigs and those seen in pernicious anemia are due to the same cause. If they are, then perhaps our work provides evidence that the factors protecting the nervous system and the antianemic substance are distinct from each other because we failed to produce macro- cytic anemia on a diet deficient in the nerveprotecting factor. Assays are being made of the antianemic potency of the livers of our animals by which it is hoped to obtain information regarding the relation between the antianemic and the nerveprotecting factors.

Perhaps the strongest evidence to support the view that there is little relationship between the factors concerned with blood formation and with maintaining the integrity of the nervous system is the fact that in a number of human disorders characterized by macrocytic anemia, and which respond to liver therapy, such as sprue, degenerative changes in the nervous system are scarcely ever found. It may or may not be significant that pernicious anemia differs from such conditions in which neurologic symptoms are rare in that a profound disturbance in gastric secretion is characteristic of pernicious anemia. This would suggest that the gastric juice may play a rôle in preparing for the body a substance necessary for maintaining the integrity of the nervous system. The observation that liver extract given parenterally seemed somewhat less effective in protecting the nervous system of the pigs than was liver extract given by mouth may, if it is confirmed, suggest a need for its passage via the gastro-intestinal tract and may point again to the difference between the nerve-protecting and the antianemic factors in liver extract. In man, the antianemic factor is 30 to 60 times as potent when given intramuscularly as compared with its effect when given by mouth.

\section{SUM MARY}

1. Abnormal gait and degenerative changes in peripheral nerves, spinal ganglia and the posterior funiculi of the spinal cord developed in pigs deficient in factors other than thiamin, riboflavin and nicotinic acid but did not occur when desiccated whole liver or brewers' yeast was fed. ${ }^{5}$

5 In an article which has just appeared (Mitchell, D., Spinal cord degeneration produced by dietary means. Brain, 1941, 64, 165) failure to prevent the development of demyelinization of the spinal cord in pigs by the feeding of yeast is reported. The suggestion is made that the pathological changes in the nervous system observed by Mitchell and by ourselves are due to a lack of some essential inorganic micro-constituent of the diet, probably copper. No experimental evidence to support the latter 
Wheat germ together with alfalfa meal was not as effective in preventing sensory neuron degeneration as liver or yeast.

2. The various fractions obtained during the manufacture of anti-pernicious anemia liver extract were assayed for their value in protecting the nervous system. The fraction used in the treatment of pernicious anemia was the most effective of all those tested but relatively large amounts were required. The value of the extract was not increased by parenteral administration.

3. Growth was better when the anti-pernicious anemia extract or the "press cake" fraction was given than when other fractions were used, but was not as satisfactory as when the whole dried liver or a mixture of all the fractions was fed. Furthermore, convulsions and anemia developed in pigs which were fed these fractions.

4. It should be pointed out that all the animals described here except those given yeast throughout the experiment received supplements of thiamin alone or thiamin, riboflavin and nicotinic acid in

view is given. Mitchell fed the salt mixture described in our preliminary experiments (1), not that used in later studies (2) or in those reported here, which contains significant and probably adequate amounts of copper as well as other metals (2). This, as well as consideration of the experiments reported by Mitchell, makes it appear more probable that his failure to prevent the development of degenerative changes in the nervous system is attributable to a lack of necessary protective factors in the yeast he used. In our earliest experiments, Experiments I and II (2), the feeding of yeast prevented the development of pathological changes only in 5 out of 12 animals. This led us to change the source of the yeast. Since type " $M$ " (Mead, Johnson and Company) has been fed from the time pigs are received, all animals have been protected successfully (Experiment III (2) and IV (in the present report)). Experimental evidence to be reported shortly indicates that the protective substance in yeast and in liver is not copper. amounts adequate to prevent deficiencies of these substances.

The cooperation of Dr. E. A. Sharp of Parke, Davis and Company, Dr. D. F. Robertson of Merck and Company, Incorporated, and Dr. Warren M. Cox, Jr., of Mead Johnson and Company, and their associates is gratefully acknowledged. Dr. Richard H. Follis, Jr., kindly examined some of the pathological sections. Messrs. Stewart Humphreys, William Thaler, Adolph Suksta, and Edward Sullivan and Mrs. Lottie Lowenstein, Miss Marjorie Lauritsen and Miss Ruth Herringman rendered valuable technical assistance.

\section{BIBLIOGRAPHY}

1. Wintrobe, M. M., Mitchell, D. M., and Kolb, L. C., Sensory neuron degeneration in vitamin deficiency. J. Exper. Med., 1938, 68, 207.

2. Wintrobe, M. M., Miller, J. L., Jr., and Lisco, H., The relation of diet to the occurrence of ataxia and degeneration in the nervous system of pigs. Bull. Johns Hopkins Hosp., 1940, 67, 377.

3. Rich, A. R., and Hamilton, J. D., Experimental production of cirrhosis of liver by means of deficient diet. Bull. Johns Hopkins Hosp., 1940, 66, 185.

4. Chick, H., Macrae, T. F., Martin, A. J. P., and Martin, C. J., The water-soluble B-vitamins other than aneurin (vitamin $B_{1}$ ), riboflavin and nicotinic acid required by the pig. Biochem. J., 1938, 32, 2207.

5. Fouts, P. J., Helmer, O. M., Lepkovsky, S., and Jukes, T. H., Production of microcytic hypochromic anemia in puppies on synthetic diet deficient in rat antidermatitis factor (vitamin $\mathrm{B}_{6}$ ). J. Nutrition, 1938, 16, 197.

6. Street, H. R., Cowgill, G. R., and Zimmerman, H. M., Some observations of vitamin $B_{6}$ deficiency in the dog. J. Nutrition, 1941, 21, 275.

7. Chick, H., El Sadr, M. M., and Worden, A. N., Occurrence of fits of an epileptiform nature in rats maintained for long periods on a diet deprived of vitamin $B_{6}$. Biochem. J., 1940, 34, 595.

8. Fouts, P. J., Helmer, O. M., and Lepkovsky, S., Nutritional microcytic hypochromic anemia in dogs cured with crystalline factor I. Am. J. M. Sc., 1940, 199, 163. 